\title{
The Effects of Human Capital by Gender on Economic Growth
}

\author{
Mohd Shahidan Shaari ${ }^{1}$, Razinda Tasnim Abdul Rahim ${ }^{2}$, Nor Hidayah Harun ${ }^{3} \&$ Faiz Masnan ${ }^{4}$ \\ ${ }^{1}$ School of Business Innovayion and Technopreneurship, Universiti Malaysia Perlis, Malaysia \\ ${ }^{2}$ Kolej Universiti Islam Perlis, Malaysia \\ ${ }^{3}$ Universiti Teknologi MARA, Cawangan Pulau Pinang, Malaysia \\ ${ }^{4}$ School of Human Development and Techno-Communication, Universiti Malaysia Perlis, Malaysia \\ Correspondence: Mohd Shahidan Shaari, School of Business Innovayion and Technopreneurship, Universiti \\ Malaysia Perlis, Malaysia. \\ Received: August 10, 2020 \\ Accepted: November 5, 2020 \\ Online Published: January 6, 2021 \\ doi:10.5430/rwe.v12n1p113 \\ URL: https://doi.org/10.5430/rwe.v12n1p113
}

\begin{abstract}
The issue of human capital by gender has been sparsely discussed in previous literature especially male labour force. The contribution of both genders to economic growth has intensified every year. Therefore, this study aims to investigate the effects of human capital by gender on economic growth in Malaysia. Data ranging from 1982 to 2018 were analysed by using the ARDL approach. The results show that higher male labour force participation rates can boost economic growth in the short run and long run in Malaysia. Higher female labour force participation rates, on the other hand, can reduce economic growth in the short run and long run in Malaysia. Therefore, the government should encourage more male labour to participate in the labour market by giving incentives. More job opportunities should be created for both genders.
\end{abstract}

Keywords: female labour force, male labour force, economic growth, ARDL

\section{Introduction}

Higher economic growth suggests that there is an increase in the output of a country and it can measure the economic performance of a country and compare with another. Boosting it can result in a higher standard of living and thus poverty can be reduced. Hence, all countries strive for higher economic growth. Based on the neoclassical theory of economic growth, economic growth is dependent on labour and capital. This means that to enhance economic growth, we have to increase labour and capital.

Romer (1990) stated the important role of human capital in the growth theory. Human capital which refers to labour can serve as a catalyst for economic growth. It is perceived to be the most important determinant in numerous previous studies from all countries. Ahmad and Khan (2018) stated that human capital can result in higher economic growth. The quality of human capital is also important to drive economic prosperity and therefore the quality is dependent on skills, creativity, training, and education. Several previous studies acknowledged that human capital with education can spur the economy to growth. For example, Shaari et al. (2014) stated that human capital with secondary education can lead to higher economic growth.

Despite the importance of human capital in general irrespective of gender, most previous studies only focused on the role of human capital specialising women in the labour force in economic growth rather than men in the labour force. This is because the recent economic growth and higher education have led them to participate in the labour market (Sarkar et al., 2019; Duarte et al., 2018) and that the proliferation of studies on female labour force ensues. Their participation is perceived to prompt higher income. Woytek (2013) found that there is a positive effect of women's presence on boards and senior management on companies' performance, leading to higher productivity and thus higher economic growth can be generated. Aznin and Norehan (2007) stated that an increase in female labour force participation may contribute to improve economic incentives in employment and policies.

However studies on human capital by gender remains sparse. Therefore, this study attempts to embark on an investigation into the effects of both male and female labour force participation as human capital by gender on economic growth in Malaysia. The importance of the male labour force in generating economic growth should be addressed as it outnumbers the female labour force in Malaysia. The issue of gender gap in the labour force has come 
to the fore when there is a higher barrier to entry for women compared to men. Hence, the number of men in the labour force is higher than women. Nevertheless, the expansion of the service sector which contributes the largest share of total GDP in Malaysia has provided more job opportunities to women. Other than that, an increase in the number of educated women has paved the way for them to participate in the labour force. Hence, the number of working women is higher than the number of working men in that sector. However, working men still outnumbers women in other sectors such as manufacturing and agriculture.

Table 1 shows the total labour force by gender in Malaysia from 2012 to 2018. Overall, it can be seen that the number of men and women in the labour force as well as the total labour force exhibit a steady increase over the years. The highest number of people in the labour force was observed in 2018 with 15, 280, 300 people and the lowest number was in 2012 with 13221600 people. The number of both men and women in the labour force showed an upward trend. From 2012 to 2013, the number of men and women in the labour force increased markedly with respective increases of $3.8 \%$ and $9.1 \%$. Despite the increasing trend for both genders, the male labour force always outnumbers the female labour force. In 2018 only, the male labour force stood at 9, 330, 200 people and the female labour force stood at 5, 950, 100 people

Table 1. Total labour force by gender

\begin{tabular}{llll}
\hline Year & Male Labour Force & Female Labour Force & Total Labour Force \\
\hline 2012 & 8419000 & 4802600 & 13221600 \\
\hline 2013 & 8739400 & 5241100 & 13980500 \\
\hline 2014 & 8823200 & 5440400 & 14263600 \\
\hline 2015 & 8952800 & 5565100 & 14517900 \\
\hline 2016 & 9012100 & 5655700 & 14667800 \\
\hline 2017 & 9213500 & 5766500 & 14980000 \\
\hline 2018 & 9330200 & 5950100 & 15280300 \\
\hline
\end{tabular}

Source: Department of statistic Malaysia

\section{Literature Review}

A vast array of previous literature have addressed the issue of human capital on economic growth (Amir et al., 2015; Shaari et al., 2014; Shahid, 2014; Atlatas \&Cakir, 2016; etc.) Some used expenditure on education as their proxy for human capital such as Pelisnescu (2015). Some, for example Xu and Li (2020), Osoba and Tella (2017) and Pelisnescu (2015), treated labour force as the right proxy to reflect human capital. Therefore, these different proxies have been attributed to mixed findings, other than methodologies and economies. Most of them found that human capital does affect economic growth positively.

Shaari et al. (2014) examined the impact of human capital using various education levels such as primary, secondary and tertiary levels in Malaysia from 1982 to 2011. The study employed the Johansen co-integration method and Granger causality and the results showed that the labour force with secondary education can influence economic growth while the labour force with primary and tertiary does not. Sahid (2014) argued that the labour force without addressing education levels does not affect economic growth. The results were based on data ranging from 1980 to 2012 in Pakistan. The study also employed the Johansen co-integration with VECM. The results also showed that gross fixed capital formation does not influence economic growth.

The following year, 2015, several studies also embarked on an investigation into the effects of human capital on economic growth. Amir et al. (2015) also used the labour force with various education levels as their proxy for human capital and their results were slightly different form the results by Shaari et al. (2014). This is because their results indicated that all education levels can influence economic growth. These results were based on the VAR method and data from 1973 to 2013. The study also argued that the labour force with education levels is the best proxy to capture human capital. Pelisnescu (2015) did not agree with Amir et al. (2013) and used expenditure on education as a proxy for human capital. The study employed pool OLS and analysed data from 2002 to 2012. However, the results were unexpected that human capital reduces economic growth. This is because an increase in 
expenditure on education, the government has to cut expenditure on other important sectors that can potentially contribute to economic growth.

Atlatas and Cakir (2016) started to examine the effects of human capital on economic growth not only in one single country but also many countries. The results were consistent that human capital can boost economic growth. The findings were based on a panel data analysis and data from 1967 to 2011 collected from as many as 65 developing countries Altiner and Toktas (2017) extended the study by Atlatas and Cakir (2016) and contributed to the findings that the effects of human capital is impaired when education is expanded. In addition, the effect of human capital is less than that of physical capital on economic growth. These findings were based on data from 32 developing countries with data period 2000-2004. Xu and Li (2020) investigated the effects of innovative human capital on interprovincial economic growth by using the panel data methods of OLS, SLM and SEM. The results revealed that despite human capital is still low in Chinese provinces, it still contributes to economic growth.

A few studies focused on human capital specialising female labour force participation. For example Serrano et al. (2019) investigated the effects of female labour force participation on per capita GDP in Latin America countries. Data were analysed from 1987 to 2014 and the results showed that regardless of the female labour force or the total labour force, human capital can still significantly affect GDP.

Several studies, such as Klasen (2018), Cabeza-García, et al. (2018) and Rakhis (2015) explored the effects of gender gap on economic growth. However, their findings are still mixed. Klasen (2018) investigated the impact of gender gap on economic growth. The study concluded that gender gap can hinder economic performance. The findings were supported by Cabeza-García, et al. (2018) who also found the same results but they conducted their study on 127 countries using the GMM method. However, Rakhis (2015) argued that there is no relationship between gender gap and economic growth in the Arab region. The study employed the ordinary least square and fixed effect method to analyse data from 19 Arab countries.

\section{Methodology}

This study uses time series data from 1981 to 2018 extracted from Department of Statistics Malaysia and the World Bank. Data is analysed by using Eviews. The data used in this study are fixed capital formation, real gross domestic product (GDP), the male labour force and the female labour force. Fixed capital formation is treated as a control variable. This study estimates using the ARDL technique introduced by Pesaran and Shin (1995) and Pesaran et.al (2001). The objective of this study is to empirically investigate the effects of labour force participation rates by gender on economic growth in Malaysia. This study uses the production function as indicated in equation (1):

$$
Y=f(K, L)
$$

$\mathrm{Y}$ represents output, $\mathrm{K}$ represents capital and $\mathrm{L}$ is labour. From the equation, we propose our model specification where labour is divided into two types, namely male labour and female labour. Therefore, the new equation is as follows.

$$
\ln G D P_{t}=\alpha_{0}+\alpha_{1} \ln K_{t}+\alpha_{2} \ln M_{t}+\alpha_{3} \ln F_{t}+E_{t}
$$

Where,

Ln: Natural Logarithm

GDP: Real Gross Domestic Product

K: Fixed Capital Formation

M: Male Labour Force

F: Female Labour Force

\subsection{Unit Root Test}

Most macroeconomic time series data have unit root or non-stationary units that can cause a false regression. In this study, data with unit root can be ignored because the ARDL method does not require all the variables to be non-stationary at level. This test is important to determine the stationarity of each variable.

\subsection{ARDL Boundary Test}

The next step in the ARDL method is to perform a bound test to examine the existence of long-run relationships between the variables and the null hypothesis, $\mathrm{H}: \delta_{1}=\delta_{2}=\delta_{3}=\delta_{n}=0$, indicates that there is no integration or no long-run relationships and the alternative hypothesis, $\mathrm{H}_{1}: \delta_{1} \neq \delta_{2} \neq \delta_{3} \neq \delta_{n} \neq 0$, indicates that there is co-integration or long-run relationships. The estimated equation is as follows: 


$$
\begin{array}{cc}
\Delta \operatorname{lnGDP} P_{t}= & \alpha_{0}+\delta_{1} \ln G D P_{t-1}+\delta_{2} \ln K_{t-1}+\delta_{3} \ln M_{t-1}+\delta_{4} \ln F_{t-1}+\text { pooooo } \sum_{i=1}^{p} \beta i \Delta \ln G D P_{t-1}+ \\
\sum_{i=0}^{p} \Omega i \Delta \ln K_{t-1}+\sum_{i=0}^{p} \phi i \Delta \ln M_{t-1}+\sum_{i=0}^{p} \psi i \Delta \ln F_{t-1}+E_{t}
\end{array}
$$

According to Pesaran (2001), the value of lower bound suggests that the variables are integrated at $\mathrm{I}(0)$ and the value of upper bound indicates that the variables are integrated at I (1). If the value of F-statistic is above the upper bound, this indicates that the null hypothesis is rejected and this means that there is a long-run relationship. If the value of F-statistic is below the lower bound, this shows that the null hypothesis cannot be rejected. If the value of F-statistic lies between the upper bound and lower bound, the decision is inconclusive.

If there is a co-integration between the variables that have been tested using the bound test, the next step of the ARDL approach is to estimate the long-run coefficient. The lag in the ARDL model is selected based on Akaike Infomation Criterion (AIC). The estimated long-run ARDL model is as follows:

$$
\ln G D P_{t}=\alpha_{0}+\sum_{i=1}^{p} \beta i \Delta \ln G D P t-i+\sum_{i=0}^{q} \Omega i \Delta \ln K t-i+\sum_{i=0}^{r} \phi i \Delta \ln M t-i+\sum_{i=0}^{s} \psi i \Delta \ln F t-i+E_{t}
$$

The next step is to estimate short-run dynamic relationships and include the Error Correction Model (ECM), the estimated equation of the ECM model is as follows.

$$
\Delta \ln G D P_{t}=\alpha_{0}+\sum_{i=1}^{p} \gamma_{i 1} \ln G D P_{t}+\sum_{i=0}^{q} \gamma_{i 2} \ln K_{t}+\sum_{i=0}^{r} \gamma_{i 3} \ln M_{t}+\sum_{i=0}^{s} \gamma_{i 4} \ln F_{t}+\varphi_{i} e c t_{t-1}+\varepsilon_{t}
$$

Where $\gamma_{i 1} \quad \ldots \quad \gamma_{i 4}$ are the short-term dynamic coefficient and $\varphi_{i}$ is the coefficient of speed adjustments to long-term equilibrium.

\section{Findings}

The results of the ADF test are reported in Table 2. The results for intercept show that $\mathrm{H}_{0}$ is accepted at level but rejected at first difference with a significance level of $1 \%$ for all of the variables, namely $\ln G D P, \ln K, \ln M$, and $\ln$. This means that all of the variables in this study are not stationary at level but stationary at first difference. The results for intercept with trend reveal that $\mathrm{H}_{0}$ is also accepted at level but rejected at first difference with a significance level of $1 \%$ for $\ln \mathrm{GDP}, \ln \mathrm{M}$, and $\ln \mathrm{F}$, and a significance level of $5 \%$ for $\ln \mathrm{K}$. This also suggests that all of the variables are not stationary at level but stationary at first difference.

Table 2. ADF unit root test

\begin{tabular}{lllll}
\hline Variables & Intercept & \multicolumn{3}{l}{ Intercept and Trend } \\
\hline InGDP & Level & First Difference & Level & First Difference \\
\hline $\mathbf{l n K}$ & -1.124546 & $-4.856782^{* * *}$ & -1.240106 & $-4.898761^{* * *}$ \\
\hline $\ln \mathbf{l}$ & -0.810398 & $-4.243472^{* * *}$ & -1.737762 & $-4.179786^{* *}$ \\
\hline $\mathbf{l n} \mathbf{F}$ & -1.206102 & $-6.033517^{* * *}$ & -2.027397 & $-6.099420^{* * *}$ \\
\hline
\end{tabular}

Note: $* * *$ and $* *$ indicate significance at $1 \%$ and $5 \%$, respectively

Table 3 shows the results of the ARDL boundary test. The results reveal that there is a co-integration at $1 \%$. The value of F-statistic is 5.794943 and it is higher that the upper value of 3.77. This suggests that $\mathrm{H}_{0}$ is rejected and thus the long-run relationship between the variables can be estimated.

Table 3. Bound test

\begin{tabular}{lll}
\hline F-statistic & \\
\hline $5.794943^{* * *}$ & \\
\hline Critical Value & & \\
\hline Significance Level & Lower Bound & Upper Bound \\
\hline $1 \%$ & 4.29 & 5.61 \\
\hline $5 \%$ & 3.23 & 4.35 \\
\hline $10 \%$ & 2.72 & 3.77 \\
\hline
\end{tabular}

Note: $* * *$ indicates significance at $1 \%$ 
The long-run coefficient based on the ARDL model is estimated for the period 1982-2018 and the results are reported in Table 4. The results show that male labour force participation rates in Malaysia can significantly and positively affect economic growth in the long run. The coefficient value is 2.705233 and significant at $1 \%$. This suggests that a $1 \%$ increase in the male labour force participation rate can increase economic growth by $2.7 \%$ in the long run. The female labour force participation rate in Malaysia, on the other hand, can negatively and significantly affect economic growth in the long run. The coefficient value is -0.730720 and significant at $1 \%$. This implies that a $1 \%$ increase in the female labour force participation rate will reduce economic growth in the long run. Other than that, the results also show that capital is found to have no effect on economic growth in the long run.

Table 4. Estimated long run coefficients using ARDL approach

\begin{tabular}{llll}
\hline \multicolumn{2}{l}{ Long run elasticity $(1,4,3,4)$} & & \\
\hline Variable & Coefficient & T-Statistic & Probability \\
\hline LNK & 0.084788 & 1.582121 & 0.1320 \\
\hline LNM & $2.705233^{* * *}$ & 7.751968 & 0.0000 \\
\hline LNF & $-0.730720^{* * *}$ & -3.143445 & 0.0059 \\
\hline C & $-6.259850^{* * *}$ & -5.747837 & 0.0000 \\
\hline $\mathbf{R}^{2}=0.942944$ & & $\mathbf{D W}=1.741938$ & \\
\hline *** indicates significance at $1 \%$ & &
\end{tabular}

To determine the long-run coefficients of the ARDL model, we estimate the error correction model. The results in Table 5 show that the error correction parameter is negative. The error correction coefficient is significant and the speed of adjustment toward equilibrium after a shock is 0.383913 . It implies that $38 \%$ of the imbalance last year is corrected to the long-run equilibrium in this current year. The results also show that capital can affect economic growth in the short run. The coefficient value is 0.206793 and significant at $1 \%$. This suggests that a $1 \%$ rise in capital can increase economic growth by $0.21 \%$ in the short run. The male labour force participation rate can also spur the economy to growth. The coefficient value is 0.538949 and significant at $1 \%$. This means that a $1 \%$ rise in a higher male labour force participation rate can increase economic growth by $0.54 \%$. However, female labour force participation rates can reduce economic growth. The coefficient value is -0.450066 and significant at $5 \%$. This indicates that a $1 \%$ rise in the female labour force participation rate will reduce economic growth by $0.45 \%$ in the short run.

Table 5. Estimated long run coefficients using ARDL approach

\begin{tabular}{|c|c|c|c|}
\hline \multicolumn{4}{|c|}{ Short run elasticity $(1,4,3,4)$} \\
\hline Variable & Coefficient & T-Statistic & Probability \\
\hline D(LNK) & $0.206793 * * *$ & 9.739799 & 0.0000 \\
\hline$\overline{D(L N K}(-1))$ & -0.038328 & -1.215638 & 0.2407 \\
\hline $\mathrm{D}(\mathrm{LNK}(-2))$ & -0.028237 & -0.996790 & 0.3328 \\
\hline D(LNK(-3)) & $0.057175^{* *}$ & 2.518683 & 0.0221 \\
\hline$\overline{D(L N M)}$ & $0.538949 * * *$ & 2.914712 & 0.0097 \\
\hline $\bar{D}($ LNM(-1)) & 0.025719 & 0.138156 & 0.8917 \\
\hline D(LNM(-2)) & $-0.555204 * * *$ & -3.135661 & 0.0060 \\
\hline $\mathrm{D}(\mathrm{LNF})$ & $-0.450066^{* *}$ & -2.505528 & 0.0227 \\
\hline$\overline{\mathrm{D}(\mathrm{LNF}(-1))}$ & 0.072305 & 0.453411 & 0.6560 \\
\hline D(LNF(-2)) & 0.188599 & 1.142046 & 0.2693 \\
\hline $\mathrm{D}(\mathrm{LNF}(-3))$ & $-0.380424 * *$ & -2.470642 & 0.0244 \\
\hline $\mathbf{C}$ & -2.403239 & -2.413593 & 0.0274 \\
\hline ECT(-1) & $-0.383913 * * *$ & -3.504765 & 0.0027 \\
\hline
\end{tabular}

Notes: *** and ** indicate significance at $1 \%$ and $5 \%$, respectively 
In order to determine the goodness of the ARDL model in this study, several diagnostic tests are conducted and the results are reported in Table 6 and. The diagnostic tests performed consist of Breusch-Godfrey Serial Correlation, Jacque-Bera, Ramsey RESET stability and Heteroskedasticity. The stability tests are performed using the CUSUM and CUSUMQ statistics. According to Pesaran and Pesaran (1997), the stability of estimated coefficients of models should be empirically investigated. The results of the CUSUM and CUSUMSQ stability tests are depicted in Figure 1. It shows that the plot of both CUSUM and CUSUMSQ graphs are within the boundaries and therefore these statistics confirm the long-run stability of the effects of labour force participation by gender on economic growth in Malaysia.

Table 6. Diagnostic tests

\begin{tabular}{ll}
\hline Test Statistic & F-statistic \\
\hline Jarque-Bera & $2.463212(0.291824)$ \\
\hline Breusch-Godfrey Serial Correlation & $0.237849(0.7912)$ \\
\hline Heteroskedasticity Test & $0.895128(0.5819)$ \\
\hline Ramsey RESET stability & $0.193645(0.6658)$
\end{tabular}

Note. The numbers in brackets ( ) are p-values.

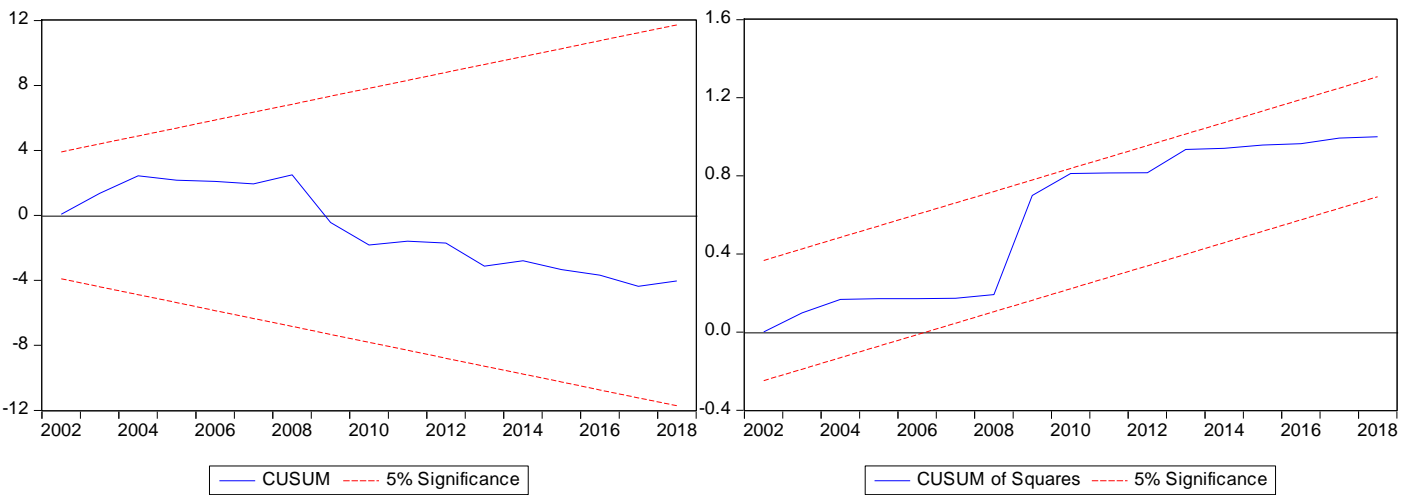

Figure 1. Cumulative sum of recursive residual (CUSUM) and cumulative sum of squares of recursive residuals (CUSUMSQ)

\section{Conclusion}

This study aims to investigate the effects of human capital by gender on economic growth in Malaysia. Data ranging from 1982 to 2018 were analysed by using the ARDL approach. The results show that male labour force participation can boost economic growth in the short run and long run in Malaysia. Female labour force participation, on the other hand, can reduce economic growth in the short run and long run in Malaysia. This is because the increase in female labour force participation in Malaysia drives the female unemployment rate to increase and this pattern is different from the pattern for the male case. Several studies supported that an increase in the unemployment rate can hinder economic growth.

These findings are important for policy makers to formulate policies on labour force participation by gender in Malaysia. Male labour force participation should be increased as it can drive the economy to escalate. Flexible working hours policy should be introduced for women in order to encourage more women to participate in the labour force. This is to ensure that they can do balancing act between family and work. Despite higher female labour force participation causing higher unemployment rates, more job opportunities should be created and discrimination against women should be dispelled so that equality can be reached.

\section{Acknowledgement}

The authors would like to thank Universiti Teknologi MARA, Cawangan Pulau Pinang for the research support and facilities. 


\section{References}

Almeida, R. A., Dickinson, J., Maybery, M. T., Badcock, J. C., \& Badcock, D. R. (2010). The radial frequency search task with additional segmentation cues. Journal of Sociology, 48(14), 4117-4124.

Australian Psychological Society. (2008). Substance abuse: Position statement. Retrieved from http://www.psychology.org.au/publication/statements/substance/

Bari, M. (2006). A distributed conceptual model for stream salinity generation processes: A systematic data-based approach. Doctoral dissertation. Retrieved from http://repository.uwa.edu.au/R/-?func=dbin-jump-full\&local_base=GEN01

Cabeza-García, L., Brio, E. B. D., \& Oscanoa-Victorio, M. L. (2018). Gender factors and inclusive economic growth: the silent revolution. Sustainability, $10(1), 121$.

Game, A. (2001). Creative ways of being. In J. R. Morss, N. Stephenson, \& J. F. H. Rappard (Eds.), Theoretical issues in psychology: Proceedings of the International Society for Theoretical Psychology 1999 Conference (pp. 3-12). Sydney: Springer.

Greenop, K. R., Xiao, J., Almeida, O. P., Flicker, L., Beer, C., Foster, J. K., et al.. (2011). Awareness of cognitive deficits in older adults with cognitive-impairment-no-dementia (CIND): Comparison with informant report. Alzheimer Disease and Associated Disorders, 25(1), 24-33.

Hatch, B. (2006, July). Smoke lingers for those who keep hospitality flowing. Australian Financial Review, 14.

Hilts, P. J. (1999). In forecasting their emotions, most people flunk out. The New York Times, February 16. Retrieved from http://www.nytimes.com

Howitt, D., \& Cramer, D. (2008). Introduction to research methods in psychology (2nd ed.). Harlow, England: FT Prentice Hall.

Jones, M. D. (n.d.). Commentary on indigenous housing initiatives. Retrieved from http://www.architecture.com.au

Klasen, S. (2018). The impact of gender inequality on economic performance in developing countries. Annual Review of Resource Economics. Retrieved November 11, 2020, from https:/www.annualreviews.org/doi/pdf/10.1146/annurev-resource-100517-023429

Lockhart, E. (2009). The physical education curriculum choices of Western Australian primary school teachers. Unpublished master's thesis. University of Western Australia.

Rakhis, M. A. (2015). Impact of gender inequality on economic growth in the Arab region. Retrieved November 11, 2020,

from https://www.sciencespo.fr/kuwait-program/wp-content/uploads/2018/05/KSP_Paper_Award_Fall_2015_AL-R AKHIS_Monira.pdf

Santhanam, E., Martin, K., Goody, A., \& Hicks, O. (2011). Bottom-up steps towards closing the loop in feedback on teaching: A CUTSD project. Paper presented at Teaching and Learning Forum - Expanding horizons in teaching and learning, Perth, Australia, 7-9 February 2001.

Thomas, K., \& Bosch, B. (2005). An exploration of the impact of chronic fatigue syndrome and implications for psychological service provision. E-Journal of Applied Psychology, 1(1), 23-40. Retrieved from http://ojs.lib.swin.edu.au/index.\& nbspphp/ejap/article/view/4/13

\section{Copyrights}

Copyright for this article is retained by the author(s), with first publication rights granted to the journal.

This is an open-access article distributed under the terms and conditions of the Creative Commons Attribution license (http://creativecommons.org/licenses/by/4.0/). 